\title{
8 Feminising an ancient human endeavour
}

\author{
Gendered spaces in mining
}

\author{
Kuntala Lahiri-Dutt
}

\section{Introduction}

Social science texts have conventionally seen mineral resources as 'gifts of nature', analysing why certain industries develop in certain locations to theorise about them. Gender did not enter into these locational conversations on mineral resource extraction. Consequently, in much of the literature on mining, gender was, to use a technical, engineering term, turned into an 'overburden'; that is disposable material treated as waste, and material that is only tangential to the major purpose of extracting the minerals that are valuable and worthy.

In spite of this neglect by mainstream social scientists, feminists from almost all disciplines have explored through this avowed gender-blind field in order to illuminate mining as a heavily gendered human endeavour. They have represented mining as gendered work where gendered labour is performed, highlighted the gendered nature of places where these various kinds of mining work are performed, highlighted the gendered contributions to working-class struggles against the capitalist exploitation of large-scale, industrial and capitalised extractive operations, the gendered nature of the impacts of mining on the host communities, and the heavily gendered nature of the organisation of mining as an industry and its role in building the gendered communities that sustained the masculine industry.

A historiography of this literature illuminates the fact that industrial production and processing of the minerals was, and remains, a gendered labour process that has distinctly gendered effects on communities, and that creates gendered places of production and reproduction. Yet, this body of literature has been lying largely hidden, unexplored and untapped, under the heavy weight of hegemonic masculinist knowledge propagated by conventional social science research.

Drawing on this feminist literature, this chapter presents the main strands of feminist arguments and brings the political economy approaches closer to the emergent threads of political ecology studies. In other words, the chapter offers an overview of the 'industrial' studies of labour by feminists coupled with feminist writings on the 'gender selective impacts of mining' emerging primarily from the studies in less-affluent nations where mining has been expanding rapidly 
since the 1980s. It argues that the masculinity of mining as an industry cannot be divorced from the gendered impacts of the industry; a masculine workplace with masculine labour processes is intimately linked to situations where women bear disproportionately heavy burdens of environmental degradation and social disruptions caused by mining activities.

\section{Feminising ancient human endeavour: gendered spaces in mining}

\section{Gender concerns: in both the industry and in communities it builds}

Social scientists from various disciplines have written extensively about mineral resources, their extraction and the mining industry. The conventional approach was to see the mineral resources as 'gifts of nature'; this approach was predominant among early economic geographers who engaged in deep locational conversations on how the natural endowments led to the development of mining industries in certain locations. These locational discussions were in exclusion to those amongst the labour studies experts who examined the class-based labour processes unfolding in capitalist developments of mineral extraction. In the volumes of literature generated by both these groups of experts of mining and society, gender figured only marginally. Undoubtedly, the spatial debates excluded human society as an active agent, but what is even more interesting is that even the debates on labour were ungendered, generally presenting the labour force as a class with a unity of purpose and similarity of interests. Experts who explored the heterogeneities within it only rarely went beyond seeking race and ethnic diversities. If mining labour were bound to their camps and compounds, so were the views of the social researchers who wrote the historiography of mining limited to a masculine manner of envisioning the world. The scholarly world was dominated by men at that time, men who were trained in the use of such words as 'mankind', and used to see men as the natural workers. One might say, using a mining analogy, that women and gender were thus treated by scholars as a social 'overburden', waste materials that are disposable and marginal to the main purpose of extracting the multitude of social, political and economic meanings and procedures of mineral extraction, processing and the distribution of finished products. Women's stories and knowledge lay hidden under layers of rock-solid masculinist normativity in thinking about mining, waiting to be uncovered by feminists from all disciplines with their eclectic methods and diverse tools.

The hegemonic masculine view of mining led to the reaffirmation, by popular literature, of the simultaneous cruelty and hellish romance of the miner's occupation, the manual character of the masculine work, the dirt and the risk. These portrayals reinforced the approaches portrayed by social scientists at the time. Such mutually supporting depictions further turned women invisible in the literature on mining. A commentary by Allen about such masculinist analysis is: 
Mining evokes popular images of hard unrefined men, distinct and separate from other workers, hewing in mysterious dungeons of coal: dirty, strange men, in some ways frightening and for this reason repellent, yet attractive because they are masculine and sensuous. ${ }^{1}$

Not just a masculine normativity in social sciences, the other reason of such gender neutrality, no, gender blindness, is rooted in a kind of 'othering' of the act of mining as a whole. Orwell's (1937) words represent this best: 'all of us owe the comparative decency of our lives to poor drudges underground, blackened to the eyes with their throats full of coal dust, driving their shovels forward with arms and belly muscles of steel'. ${ }^{2}$ This othering led to, as Campbell observed, turning the male miner into an iconic figure:

Miners are men's love objects. They bring together all the necessary elements of romance ... It is the nature of this work that produces a tendency among men to see it as essential and elemental, all those images of men down in the abdomen of the earth, raiding its womb for the fuel that makes the world go round. The intestinal metaphors foster the cult of this work as dark and dangerous, an exotic oppression . . . it constructs the miner as earth-man and earth-man as true man. And it completed the equation between some idea of elemental work and essential masculinity. This romance is duly mirrored in working class politics - miners are the Clark Gables, the Reds of class struggle. ${ }^{3}$

This chapter steps away from such avowed gender neutrality and illuminates the extractive industries as gendered places of work at various scales. In addition, it also illuminates the industrial production and processing of the minerals as a gendered labour process having gendered effects on communities. It draws on the growing body of literature that has been built by feminist researchers over the years, literature that has been lying hidden, unexplored and untapped, under the heavy weight of hegemonic masculinist knowledge propagated by conventional social sciences. In this context, it is imperative for feminists to ask two central questions to expand the discourse. The first question is why there exists a need for feminists to consider mineral extractive industries such as mining, and the second is through what approaches we should study mining.

My objective is to present the major strands of feminist arguments arising from approaches that are based on both political ecology and political economy. Thus the chapter presents an overview of the 'industrial' studies of labour by feminists, coupled with feminist writings on the 'gender selective impacts of mining' emerging primarily from the studies in less-affluent nations where mining has been expanding rapidly since the 1980s. Indeed, the masculinity of mining as an industry cannot be divorced from the gendered impacts of the industry; a masculine workplace with masculine labour processes are intimately linked to situations where women bear disproportionately heavy burdens of environmental degradation and social disruptions caused by mining activities. ${ }^{4}$ 
Images of mining that have conventionally been invoked by social researchers dealing with extractive industries continue to be masculine, illustrating not just the rough, dangerous and manual nature of the work as it used to be but also a new kind of masculinity that is associated with power that emanates from the capital that such industries represent. An in-depth exploration of these representations is impossible within the limited space of this chapter. Suffice it to say that it is possible that the equation of modern mining with the 'death of nature' by ecofeminists such as Merchant ${ }^{5}$ came from an association of women and nature, and the obvious analogy of mining violating a sacred mother's womb. This association remains of feminist interest and may require further exploration because for most of human history, as Mircea Eliade ${ }^{6}$ shows, people actually believed that minerals grow organically inside the earth, drawing an analogy between obstetrics and mining, equating the mineral ore to the embryo, a mine to the uterus, a shaft to the vagina, and the miners to obstetricians. Such gendered symbolism about mining can also be detected in the work of anthropologist Michael Taussig $^{7}$ (in interpreting the changing belief systems surrounding mining in Latin America). Taussig documented that as Bolivian peasants were transformed into industrial proletariats, their incorporeal mother earth and the benevolent spirit of pachamama changed into the idol of an unpredictable male devil that inhabits the underground and who, instead of being worshipped, is feared by all.

Traditional social research on mining has conventionally explored less of this symbolic domain and more of the real or the absolute space that minerals and mining occupy. The thematic areas that have been explored by conventional social science research until now have included the 'special' nature of mining settlements that defy any spatial modeling, the widespread in-migration into mining areas leading to rapid and widespread urbanisation, and the 'place identity' that extensive mining of minerals such as coal creates - whether in mining camps or over extensive regions. As a feminist researcher, one cannot help but observe that each of these areas of research can be gendered. Indeed in recent years, feminist contributions to labour studies and to the examinations of economic work have brought to light women's key roles in building the mining industry and constructing coherent mining communities.

This chapter summarises these feminist contributions under four broad (and somewhat overlapping) heads: mining as a gendered industry or a workplace (or women and men in mining); the working class struggles by mining workers as gendered which studies the gender interstices of home and work in mining communities; and mining as a global/national agent of capital accumulation and dispossession of the poor in the contemporary world. At the end of the chapter, I offer some possible directions for future feminist research on mining.

\section{Women as economic agents: mining as a gendered industry}

Influential authors such as Lewis Mumford $^{8}$ and Carolyn Merchant, ${ }^{9}$ who were familiar with the extractive industries that came into existence in Europe and America after the Industrial Revolution, saw these industries as one of 
the ultimate expressions of modernity - a metaphor of the modern world representing capitalist exploitation of labour and the gross commodification of nature by the hegemonic corporate enterprise. The extraction of mineral commodities was instrumental to capitalist exploitation as coal and iron ore formed the backbone of modern industries that built themselves on the manual labour performed in the mines (and factories). Humphries offers a Marxist explanation, pointing out that the rural poor in the late eighteenth and early nineteenth century England enjoyed non-legal but insuperable customary and common rights to local agricultural resources. ${ }^{10}$ The loss of these resources through enclosures changed women's economic positions adversely within the families as their dependence on wage (and wage earners) increased.

No matter how much the ecofeminists such as Carolyn Merchant equate nature with women, there is no doubt that women have been in the mines with men, as part of a family labor unit, from early times. In between the early days and contemporary times that have seen women return to mining work, there was a brief period - following the 1842 Mining Act of the UK and measures by the International Labour Organization (ILO) to stop women's work at night shifts and in underground - when women were prevented from working in the mines. In early mining, there was hardly any difference between it and farming in terms of peasant production strategies. Both were family-based production, carried out primarily to ensure the subsistence and survival of the household unit. This is evident from the depictions in early treatise such as De Re Metallica ${ }^{11}$ that portray women as taking on the tasks of breaking and sorting of ores, hauling and transporting them, participating in the smelting and processing activities, and sometimes even undertaking the physically demanding job of working the windlasses. Vanja outlines women's contributions in preindustrial mining of an artisanal nature in Europe, where women worked in small pits and smelted ore. ${ }^{12}$ This tradition of women accompanying men into mines continued into the colonial period when the major gold rushes took place in the 'New Worlds' of America and Australia. Some women, however, went into the mines on their own volition and not just to 'service' the men or as supplementary labour; the fact that some women prospected for gold during major rushes such as in the American West has been well-documented by Zanjani. ${ }^{13}$

The transformation of Europe and Anglo-America into industrial societies was possible because of a mineral extractive boom. This boom led to a mushrooming of collieries and iron ore mines, in addition to silver and gold mining. Early feminist scholars ${ }^{14}$ noted that women played a key role in Industrial Revolution as the home and the workshop became separated and a great number of them turned into wage earners in the outside world. The contributions of women, although apparently wiped out from the mainstream consciousness, become visible in odd places and memorialised as a forgotten past; for example, the museum (Musée D'histoire Naturelle et de Géologie) in Lille, in northern France, has statues of women colliery workers in their work clothes. Similarly, in the Kohle Global exhibition in the Ruhr Museum in Essen, the contributions of women colliery workers of the time are celebrated. These early modern or capitalist industrial mines also saw the 
participation of women in large numbers. In the mines in Belgium until the early twentieth century, 'numbers of women working underground in Belgian coal mines actually grew ... [and] ... Belgium's women coal-miners earned some significant portion of the public respect and reverence elsewhere given so readily to male coal-workers'. ${ }^{15}$

Women coal mine workers came to be known as hiercheuse, a proud title connoting the feminine version of mineurs, the male miners. Hilden further goes on to narrate that while the male miners wore hard leather helmets, trousered suits and wooden clogs, the hiercheuses were dressed in white linen suits of knee-length trousers and a buttoned, long-sleeved jacket. Groups of women worked in shifts, going down the mine at $5 \mathrm{am}$, and returning at about $9 \mathrm{pm}$, loading between 60 and 70 chariots during these hours.

One might expect that European colonial powers would also hire women when they were establishing mines in the colonies, but that was not the case. In contrast, early Indian colliers initially employed women as part of a 'family labour' system that kept the workers, often drawn from local tribal communities, tied to the modern industrial mines. ${ }^{16}$ With respect to South African collieries, Alexander has shown that the colonisers hired male black men and kept them in barracks, strictly separate from those of the white workers. ${ }^{17}$ The job division in the pits meant that kamins (female workers) performed quite different tasks from those performed by the coolies (male workers) in India. ${ }^{18}$ The kamins worked not only as the 'gin girls' (from the term 'engine') to lift coal from the shafts, but also as loaders of coal (cut usually by their male partners - father, brother or husband) in both surface and shallow underground or open cast mines that were locally known as pukuriya khads. A similar pattern of sex-based labour division existed elsewhere in modernising Asia as well; Nakamura describes the naya ('stable') system of work in Japanese coal mines:

A working pattern in which a married couple worked as a unit, with the husband (sakiyama) digging out the ore and the wife (atoyama) assisting him by carrying away the coal, became widespread [during the early twentieth century]. Married women comprised most of the female workforce in the coal mining industry. ${ }^{19}$

The naya system was an indirect labor management system with the naya chief as an agent, who recruited the miners, and then made them live in the bunkhouses he provided, and supervised their daily lives. Monies borrowed from him kept the miners in bondage to him.

However, in spite of this long and impressive history, the issue of women's labour in the mines remains an area fraught with controversies owing to four main reasons: sex-segregation of jobs that pushed women into relatively lower-status jobs compared to those performed by men; the marking of tasks as male and female tasks which created spatial segregation within the mine or even the pit; the prevalence of a family wage that meant women hardly ever received the full recognition for their component of labour; and the various protective legislations, 
largely initiated by the International Labour Office during the 1920s, around women's labour in mining. Women's labour in mines within a strict sex-based division of tasks was (and still remains) subject to gender ideologies - situated in the home as well as those propagated by the state. Protective legislations define women as 'special workers'. This 'special' nature of women workers is conceived by labour experts in three ways: women's 'natural' task is reproductive labour; their physical frailty circumscribes the kinds of work they can do; and as dependents unable to uphold their own interests, they require the protection of the state. Discourses on the nature of women workers as 'special' build, reinforce and perpetuate a 'maternal wall', bringing women's domestic and reproductive roles to the fore, rather than their productive roles. Populist and universalist conceptions of femininity and womanhood tend to naturalise contested gender norms through these protective legislations that are problematic and that eventually operate against women's interests. Their long-term policing effects are evident, as in the mines, where masculinities became inscribed onto the bodies of miners and into the spaces of mining.

Not only in the workforce, the relationship between gender ideologies and the sex-based division of labour has meant that women's unpaid labour as part of the family has also remained largely invisible. This is more than evident in mining communities where men were seen as the primary workers and women were seen simply as supplementing their labour. Describing women labouring in early modern collieries in England, John argued that since the male members utilised the labour of their female relatives, those women who worked as 'pit-brow lasses' (those who worked at the brow of coal pits) were not usually recorded in colliery accounts by the government officials who were in charge of keeping records. She observes:

In the eighteenth century the employment of women was still part of a family concern, male members utilising the help of their female relatives wherever possible. Since the hiring and payment would be the responsibility of the male collier, women were not usually recorded in colliery accounts. ${ }^{20}$

This invisibility that ensured the maintenance of masculine dominance within the household also meant that the division of able-bodied and the disabled was not sharply drawn and the male was presented as the head even when physically ill because the central concern to mining families was to ensure the physical wellbeing and continued wage-earning capacity of male bread winners. ${ }^{21}$

The relationship between state gender ideologies and economic imperatives meant that women were encouraged to join the mining industry at the convenience of the state. For example, Ilič has documented that despite the fact that the Soviet Labour Code included a ban on the employment of female labour in underground work, women continued to work extensively and in increasing numbers throughout the interwar period in response to the need for additional labour. ${ }^{22}$

These factors made women's labour invisible. Clearly, official employment records do not show the full extent of women's participation in mining. 
When government officials visited an asbestos mine in South Africa in 1950, they found the records showed that the mine employed 100 males but made no mention of women. A month later, a health inspector, also from the government, visited the same mine and noted that there were 102 male employees and 40 women. ${ }^{23}$ Such discrepancies occurred because of women's invisibility as workers, but not necessarily as individuals with health-related problems.

In retaliation for the invisibility of women mine workers in government records, feminist labour historians have resorted to alternative sources of documentation such as oral histories. For example, Gier and Mercier ${ }^{24}$ and Tallichet ${ }^{25}$ have used oral histories of women mine workers in the mid-Western regions of the USA and in central Appalachia respectively in order to unearth their hidden histories.

The most remarkable phenomenon in the contemporary world is a 're-feminisation' that the extractive industries are experiencing. After decades of being known for its hyper-masculine labour regimes, the awareness of the differences of women's issues compared to men's - low participation in formal, industrialised mining and its excessive impacts on women in mine-affected communities - have enhanced the visibility of women/gender in extractive industries. Equal employment opportunity principles have opened up hitherto out-of-bounds jobs for women in countries such as the US and Canada, and as large-scale industrialised capital charts out its new territories in the countries of Global South, it is absorbing women into some of the mining operations. ${ }^{26}$ Some countries with large mining sectors, such as South Africa, have created new rules for hiring women, primarily in order to ensure that some benefits, such as cash incomes, flow to women in mining communities. Increased awareness of the need for greater equity between genders has forced large mining corporations, irrespective of actual position of women in these companies, to highlight women in their public profiles. Together, one can say that these are driving the re-feminisation of mining, posing a challenge to scrutinise the process to understand multiple aspects of women's engagements with diverse forms of extractive processes, and link them to gender equality. One can detect increased inclusion of 'gender' in policies and processes of formal, capitalised mining such as in social impact assessments, ${ }^{27}$ community engagement, ${ }^{28}$ mining companies' negotiations and agreement-making, ${ }^{29}$ sustainability reporting, ${ }^{30}$ women's access to local economic and community development, services and infrastructure, ${ }^{31}$ inclusion of Indigenous women ${ }^{32}$ and provision of job opportunities. ${ }^{33}$ Responses to women's concerns in industry initiatives have been much slower than other natural resource management sectors. ${ }^{34}$ Progress on the ground has been limited because mining company personnel rarely question patriarchal systems in mine-affected communities for fear of offending 'custom'. ${ }^{35}$ However, in terms of numbers alone, the proportion of women remains low in large, industrial mines.

Moreover, a number of issues remain poorly debated; for example, even in countries with affirmative actions in employment opportunities, women continue to experience discrimination in various ways and forms that are not clearly understood from numbers alone. ${ }^{36}$ The vulnerabilities that women experience do not become apparent from the win-win arguments proposed by mining corporations 
on their glossy pamphlets and professional websites. ${ }^{37}$ Yet, cumulatively, all these indicate the fact that both international pressure and gender awareness are building, and the awareness of women's contributions to mining as an industry and as a workplace is increasing.

\section{Women as reproductive agents: mining wives building up the community and family}

Linda Rhodes lived in mining camps as the wife of a mining engineer. Based on her personal experiences, she shows how unpaid labour by wives - at home and in the community - helps sustain a flourishing social life around mines. ${ }^{38} \mathrm{Her}$ observations are supported by the earlier observations of Robinson who documented that the managers' wives in a mining town in Indonesia were expected to take on leadership and welfare roles in the community through involvement in the Association of Inco Families, an organisation in which their position paralleled that of their husbands. ${ }^{39}$ In other words, they were constructed as an auxiliary branch of the capitalist enterprise of the mining company. Broadly speaking, this illustrates the meaning of mining culture, a culture that attributes domesticity to miners' wives by socially constructing and locating women within the home in mining communities. These women can then be described as 'the hewers of cakes and drawers of tea', and relegated to their place at home for men to gather in union halls (or local pubs) in order to form their class-solidarity. ${ }^{40}$ Marxist geographers McDowell and Massey in their research on the colliery settlements of Durham, England, analysed this phenomenon as one of gender divisions of labor creating a spatial division between the home and workplace (the mine). ${ }^{41}$

Mining settlements are not organic and can be seen as 'remote' and a kind of exception to ordinary settlements. ${ }^{42}$ More importantly, the communities who inhabit these settlements comprise of new migrants, building up a 'new' community, whose very existence is ruled by the state, the company and labour organisations - all male-dominated institutions. ${ }^{43}$ Klubock's study of a copper mine community in Chile shows how transnational mining capital and the state ignore the complexities of gender within the community in monitoring men's and women's roles and behaviours, thus engineering a shift to the male headof-household model. ${ }^{44}$ Anthropologist June Nash put women in Bolivian mining communities within the context of the home as wife of a male miner, subjected to the limitations of the house, to the dominance by the man whose needs she must dedicate herself to and to almost continuous childbearing: 'Male and female roles are dichotomized in the mining community, and there is still a mystique about women not entering the mine'. ${ }^{45}$ Women in mining communities are therefore seen as belonging to the working class because of their men, the 'male contoured social landscape' burgeoning with the tacit as well as overt support from the company (for example the Anaconda Copper Mining Company in Butte, Montana ${ }^{46}$ ).

This statement continues to be broadly true of all contemporary mining settlements. Not just the larger company town but also the camps meant for mine workers living close to the pits are highly structured along class hierarchies. ${ }^{47}$ 
In these settlements, company hierarchies are reproduced within and between social spheres to provide an informal instrument of subjugation for those occupying a lower status at work. Managers' wives have relatively higher social and economic status than the wives of staff members and much more so than the local or indigenous women, who in turn, then develop a heightened awareness of class and wealth. Also, in multinational operations, race too can play an important role in segregating places according to the complex intersection of gender, race and class. ${ }^{48}$

Undoubtedly, the mining communities are where everyday lives are performed and gender is constructed and enacted through the processes of daily production and consumption. Feminists' interests emerge from the fact that gendered people from these communities occupy the interstices of home and work. The contrasting female identities - of the domestic woman versus the political woman (or the economic woman) - become a key force in reinforcing normative gender roles by ascribing certain tasks to the individuals from each sex. The majority of domestic women shoulder onerous maternal and domestic burdens of unpaid domestic and emotional work, and accept male subordination to fit the picture. This is fast becoming the norm. To what extent women have a degree of autonomy in producing their identities is still unclear. ${ }^{49}$

\section{Women as political agents: active in mining struggles}

It is important to note that women are not only workers in the mining industry. They are also political agents who are active in mining struggles. Throughout the history of modern industrial mining development, they have fought (and continue to do so) against exploitation, either standing side-by-side with men or in the wings by providing critical support and logistical assistance. Their efforts have helped in the maintenance of solidarity as part of the working class. Mining and gender literature also uncovers the histories of, and presents, women who helped the male (and female) workers to protect both their families and their collective interests. The archetypal images of women protesting against capitalist exploitation in mines are contained in Emil Zola's masterpiece, Germinal, ${ }^{50}$ set in the context of the coal miners' strike in northern France in 1860 and in particular, that of the inspirational Mother in Maxim Gorky's $1906^{51}$ novel about Russian factory workers. It is important to remember, however, that the struggles of industrial mine workers, which such images represent, are somewhat different from the contemporary struggles portrayed in the social movements and resource conflicts literature.

Throughout the industrial world, coal mine workers often led the demands for improvements in working conditions, and women were an auxiliary force in these class movements. While women supported workers' struggles against capitalist exploitation and mine closure, and even confronted management directly over issues like food and housing, they also adopted an impressive number of strategies to ensure their own position. Their strategies often pitted gender against gender and even occasionally transcended class lines. Women activists, even though 
working for auxiliaries, sometimes acquired considerable power by refashioning the rhetoric surrounding motherhood and through the deployment of strategies to organise themselves. ${ }^{52}$ Another strategy involved closer self-observation of women and their relationship with the trade union activists. ${ }^{53}$

The crucial roles women played in miners' strikes were invaluable, as they not only supported men's struggles, but also took up activist roles themselves to be the 'voice' for their own concerns. Describing the more recent strikes in the Bowen Basin in Australia in the 1980s or the dispute with the Australian mining company, BHP in 2001, Murray and Peetz comment on the support that women gave to striking miners and to each other: 'without this support it is questionable whether any of the actions would have succeeded. ${ }^{54}$ Similar stories have been documented of miners' strikes in other countries. Stead for example, described women's roles in the miners' strike in Britain during 1984-85. ${ }^{55}$ The key areas that emerged include not just the unpaid work by wives and the economic support they provided to families through the crisis by adopting diverse economic activities, but also their active political roles as protesters representing class interests.

The supportive roles played by women in mining struggles are legendary. However, some feminists have critiqued this view based on the conflicts in class and gender identities that never make women an integral part of mining unions anywhere in the world. Indeed, the politics of socialism, in which miners have historically played a central part, tends to generalise and present a fictitious character of 'the miner's wife' who supports men's struggles in solidarity.

Trade unions were most often insensitive to the needs of women as workers and held working-class interests as representing the interests of all workers, irrespective of their gender. For example, in Indian collieries, the need to improve working conditions was advocated by male-dominated trade unions, which could only bargain for higher wages on the grounds of a shortage of sufficiently skilled labourers to operate the machines. The camaraderie of male-dominated trade unions, a vital asset in the struggle against labour exploitation, has compounded the marginalisation of women workers in Indian coal mines, where most women mine workers are illiterate and from lower castes or indigenous groups, turning the male miner as the archetypal 'working class', subsuming women's interests in the mining industry. ${ }^{56}$ In some instances, the ideal of dual unionism (separate unions for female and male workers) meant that women's unions were always lower in status, poorly staffed and had a largely ineffective voice. The All India Trade Union Association, founded in 1920, dealt with 'women workers' issues' by forming separate trade unions for women. The separation of women's interests as 'special' and different from 'general workers' issues' meant that men in trade unions dealt with 'bigger' and more pressing agendas. This separation, though changed later, left a legacy by segregating Indian working-class interests on a gender basis, and by encouraging a view of the industrial labour force as the domain of male workers. In 1960, Sengupta observed that 'the question of women in Indian industries is still considered in many circles as a minor problem compared to other labour problems'. ${ }^{57}$ Little had changed by 1997, when Fernandes observed that 'the question of gender has been viewed by unions as 
a marginal concern' ${ }^{58}$ This is because the conventional wisdom of trade union leaders is to deal with what they see as the most important problems such as lockouts and mass retrenchments. These so-called 'bigger' problems continue to subsume issues relating to the position of women workers within the trade unions in Indian collieries. ${ }^{59}$

Mining corporations are aware of this social need of mining communities to conform to gender ideologies and being gendered organisations, they exploit this social need and themselves push women into domestic spaces. In the past, in mining towns of the Northern Rhodesian copper belt, mining corporations encouraged more mine workers to live with their wives at home to enhance the 'stability' of the labour force, while women wrestled with their 'male protectors' for access to family incomes. ${ }^{60}$ Although a woman's potential prosperity largely depended on her husband's wages, higher wages alone did not guarantee a woman's financial position. In contemporary times, large mining corporations take up other strategies such as building women's clubs to create and reinforce a strong occupational identity that overall emphasises women purely as reproductive agents by placing them as part of the home and the community.

\section{Women as victims: dispossessed by mining}

In contrast to the historical literature, contemporary feminist studies have primarily used the lens of political ecology to analyse the literature on mining. The reason for this may possibly be attributed to the fact that since the $1980 \mathrm{~s}$, most new and large mining projects have been established in less-affluent countries; very few nations of the industrial world can still claim to have a thriving mining sector, except the USA, Australia and Canada. It is also possible that this selective focus is reminiscent of the bias expressed by Mumford and Merchant, which I referred to earlier in this chapter.

Collectively, this genre of research has emphasised that the introduction of large-scale mining affects women disproportionately. The impacts on women are more severe than that on men. These impacts range from the erosion of the physical subsistence base to social and cultural changes such as changed notions of authority and interpersonal power equations both at home and within the communities. Women are affected both by lack of access to assets and resources, as well as increased cash flows into local economies which predominantly fall into the hands of men. The gendered impacts often cut across class and race, but women (and men) who are already at a disadvantaged position within the socio-economic hierarchy are more adversely affected by large-scale mining than their more privileged counterparts. Again, the gender-selective impacts have been noted both in economically well-developed countries such as Canada as well as in less-developed countries with smaller economies. For example, Hipwell et al. noted three broad categories of gendered impacts of mining on the Indigenous populations in Canada: those affecting women's health and well-being, those affecting women's work and traditional roles and those affecting the (unequal) distribution of the economic benefits from mining. ${ }^{61}$ 
Equally important to their discussion were the loss of traditional autonomy and the changes in the productive roles of women.

In less-affluent countries, the family unit's food security primarily burdened already fast-depleting subsistence bases combined with environmental degradation for women. ${ }^{62}$ Degradation in the physical environment in mining areas occurs due to the contamination of air, dust and water from activities related to mineral extraction and processing. Positioning the problem in the environmental justice paradigm ${ }^{63}$ leads to the observation that the alienation or loss of productive agricultural lands, reduced access to water sources, the loss of livelihood opportunities and the loss of forest cover negatively affect women more than men. Bhanumathi also observed the decreased ability of women to work on remaining land as men tend to migrate out of villages to cities in search of cash incomes. ${ }^{64}$

In her early ethnographic work on the political economy of development in a mining town in Indonesia, Robinson observes that 'The fundamental change in Soroako has been the loss of the village's most productive agricultural land to make way for the mining project' ${ }^{65}$ Therefore, the loss of productive land rapidly transforms a large proportion of male villagers dependent on wage labour for the company, reducing them to a semi-proletariat. Generally, women tend to become less active economically due to a sudden change in the production systems, relations and spatial orientations according to Rothermund. ${ }^{66}$ Consequently, women in mining tracts in India sometimes resort to a variety of activities in the informal sector, or become more homebound than before. As cultural expressions of gender change, both women's autonomy and personal freedom which they may have enjoyed earlier either become restricted or decline altogether. As the community changes from peasant agriculture to wage labour for subsistence, women generally experience a decline in their economic independence.

Mining projects are highly capitalised; their heavy equipment, offices, roads and other infrastructure, salaried workers and their residences introduce a new cash-based economy into a rural area. Often these cash incomes actually play significant roles in reducing women's autonomy. A variety of social and cultural impacts occur when large numbers of migrant population disrupt the social fabric of a mining area. The loss or changes to traditional culture remove some of those older cultural norms that might have attributed some authority and power to women. Thus, the loss of older values often more adversely affects women than men; the effect is particularly evident in the devaluation of women's productive work at home and by undermining their status as decision makers and landowners. In the Pacific islands, a sudden influx of mining revenues within local communities generally marginalises women. In general, the monetised economy introduces a different 'mining culture'. This external culture is reinforced by the mining company which attributes new notions of authority to men, putting women either in lower-status jobs or rendering them invisible by involving men in decision-making processes relating to issues of compensation and agreement making. When a mining corporation negotiates with the community, the latter is most often represented by traditional leaders who are usually elders and of the male gender. This happens because being gendered organisations themselves, 
the mining corporation personnel are usually also male, who carry with them false assumptions about who might be the 'head of the family', or how household resources are allocated among the members. Usually, the land belongs to men, and more often than not, men receive monetary compensation for the loss of land, making it difficult for women who have little formal political authority to be able to influence how the mine shapes their autonomy in decision making and, in a broader perspective, their lives.

One interesting dimension in determining the winners and losers of the mining projects among women is their geographical distance from the mining operation. In a study carried out in eastern Kalimantan in Indonesia, it was found that generally, physical proximity to the mines leads to the direct experiencing of noise and vibrations, and the visibility of gigantic machines arouses fear and a sense of insecurity creating a heightened sense of negative impacts for women according to Lahiri-Dutt and Mahy. ${ }^{67}$

The entry of a cash-based economy with mining also affects women indirectly. The extra cash earned by men being spent on sexual promiscuity, on pubs, karaoke bars and brothels that come up overnight in the most remote places. Lahiri-Dutt and Mahy observe that generally speaking, the negative gender impacts of mining are related to the shifting power equations within communities and families. These shifts can be specific to a particular person or groups, and they also include the increased cost of living, the lack of direct employment opportunities in the mine for women, environmental impacts and women's lack of decision-making power at the community level. All these shifts translate into a dependency on male relatives. ${ }^{68}$

Reflecting on the literature that relates to the impacts of mining on women, one observes that it has reaffirmed the role of women as victims of multinational capital that destroys the environment and adversely affects the lives of the poor. Of the several victim figures, the most convincing and lasting one has been that of 'the prostitute' who has been turned into one by mining projects and who makes a living selling sex around the mine site. Again, as a metaphor, this has been interpreted as equal to the vandalisation of nature by mining, thereby causing the degradation of women by degrading the land. Indeed, the attitudes towards both sexuality and towards women change with the rapid influx of money and new social-cultural values. ${ }^{69}$ For example, while many societies in Papua New Guinea incorporated long periods of male sexual abstinence, there is evidence that in mining towns this is being eroded. Macintyre notes that mining communities report a growing incidence of alcoholism, rape and other forms of violence against women and an increasing incidence of teenage pregnancy. ${ }^{70}$ However, the theoretical positions of much of this evidence have been questioned in recent years. ${ }^{71}$

$\mathrm{O}^{\prime}$ Faircheallaigh ${ }^{72}$ and Lahiri-Dutt ${ }^{73}$ have critiqued the theoretical basis for viewing women only as victims of social and economic change. Overall, attention to gender can lead to more sustainable livelihoods for mining communities. ${ }^{74}$ This discussion is the derivative of the highly contested literature on women, environment and development (WED) which emphasises the affinity of women with their environments, is reminiscent of biological determinism 
and essentialism and characterised by the absence of social, material or historical context. This literature homogenises all women as a single category, and romanticises their special closeness to the environment at the cost of exploring the intersection of race, ethnicity and class relations. This scenario leads to the danger of depoliticising the environmental and community politics in mining and creates a dualism between women and men with separate spheres and spaces of production.

\section{Conclusion}

As is apparent from the discussion above, I clearly needed to rely more heavily on certain specific disciplines within the social sciences in writing this chapter that is intended to address a broad audience generally interested in mining. While feminist historians have contributed generously in 'uncovering' the hitherto hidden histories of women in mining, more contemporary studies have focused on the political ecology of mining as the industry has moved into the less-affluent countries, impacting on the poorer and the disadvantaged in general but more specifically women from these communities. It turned into quite a challenge to find contemporary studies of labour processes within the mining industries of these countries. In a way, I see this as an important turn within feminist studies of mining: from the earlier pure emphasis on labour processes in the mining industry and its associated spaces, feminists are using a combination of political economy and political ecology to deepen their understanding of gender both in the industry and how it impacts on the mining communities.

Tentatively, I can only speculate and offer some broad and general views for this paucity in the creation of new knowledge on gendered perspectives on mining and vice versa. In my view, one of the reasons lies in how most social researchers see mining: quintessentially as the 'other', as a human endeavour that is 'not natural' and one that competes with farming for land; that is physically remote and scattered; that is associated with chance or luck; that does not yield itself easily to modeling; and finally, one that represents a 'special' kind of human project in its disregard for preserving nature/the environment. More significantly, the paucity of information may also have to do with the subjectivities of many feminists whose works dominate mining literature: their general location in industrial nations in many of which mining has become a part of history, and their position as second-wave feminists with left-leaning politics which makes them uncomfortable with the fact that capitalised mining has expanded rapidly into the less-affluent nations since the 1980s where the gender and class equations are somewhat different.

Therefore, in thinking about contemporary mining in these countries, some feminists put aside their historical understandings of race/class/gender, and find it easier to adopt a lens of political ecology to show that poor women are leading the protests against mining operations that undermine the very basis of their survival. These contributions are significant to the social studies of extractive industries, but they in a perverse manner naturalise men as mine workers 
usurping benefits and therefore reaffirm women as either the victims or as agents resisting against mining, further reaffirming women as 'the other' of mining and the miners, equivalent to mother nature.

From my position at the margin of margins, I can only indicate the possible directions of future research on gender in and gender and mining through a feminist lens. The body of knowledge that developed in the context of modern industrial mining remains invaluable and will remain so, but tomorrow's feminists would do well to engage more with four main sets of theories: postcolonial feminist perspectives that critically reflect on power relations, intersectionality, feminist political ecology and related but not quite the same, gender and development (GAD) theories. They would explore how mining impacts not just on all women as a homogenous group but how gender creates advantages as well as disadvantages selectively. They would explore deeply how gender can be integrated within the mining 'project cycle', that is, from the stage of exploration to that of closure, and by engaging with the mining communities, companies and policy makers, would offer new solutions to the continued invisibility of women and gender. They would also show how the new working classes brought into existence in less-affluent nations by contemporary capitalised mining projects are essentially differentiated not just in their rural roots but also in the new, flexible, work arrangements (such as Fly In Fly Out or FIFO), and in how gender is (re) negotiated in the fluid spaces and selves created by these arrangements. They would explore what race and age mean for women and men in mining camps and towns, thereby focusing on how the gendered bodies of individual men and women perform certain kinds of work, how masculinity (and femininity) of the enterprise is transmitted into the communities, and the gendered social lives within these communities, as well as the implications of the intricate sexually based division of labour within mining organisations.

\section{Acknowledgement}

I prepared this chapter during my stay as a Senior Visiting Fellow at the Asia Research Institute (ARI) of the National University in Singapore (NUS). I thank both ARI and NUS for providing me with an engaging academic environment that immensely facilitated this writing project.

\section{Notes}

1 Vic L. Allen, The Militancy of British miners (Shipley: Moor Press, 1981), p. 4.

2 Orwell, George, 'Down the Mine', in Collected Essays (London: Secker and Warburg, 1937).

3 Beatrix Campbell, Wigan Pier Revisited: Poverty and Politics in the Eighties (London: Virago, 1984), p. 97.

4 A caveat is better mentioned up front: this chapter does not explore informal mineral resource extraction that has been a central plank of my recent feminist critique of mining: Kuntala Lahiri-Dutt, 'The shifting gender of coal: Feminist musings on women's work in Indian collieries', South Asia: Journal of the South Asian Studies Association 35(2) (2012), pp. 456-476. 
5 Carolyn Merchant, The Death of Nature: Women, Ecology and Scientific Revolution (San Francisco, CA: Harper, 1990).

6 Mircea Eliade, The Forge and the Crucible: Origins and Structure of Alchemy (Chicago, IL: University of Chicago Press, 1962).

7 Michael T. Taussig, The Devil and Commodity Fetishism in South America (Chapel Hill, NC: University of North Carolina Press, 1980).

8 Lewis Mumford, Techniques and Civilisation (New York: Harcourt Brace and Company, 1934); and Lewis Mumford, The Myth of the Machine, Vol 2: The Pentagon of Power (New York: Harcourt Brace Jovanovich, 1967).

9 Merchant, The Death of Nature.

10 Jane Humphries, 'Enclosures, common rights, and women: The proletarianization of families in the late Eighteenth and early Nineteenth centuries', The Journal of Economic History 1(3) (1990), pp. 17-42.

11 Agricola Georgius, De Re Metallica, translated from the Latin by H. and L. Hoover, (New York: Dover Publications Inc., 1556). This was the first European mining textbook to contain numerous woodblocks depicting women carrying out these tasks. Also see Pamela O. Long, 'Of mining, smelting, and printing: Agricola's "De re metallica"', Technology and Culture 44(1) (2003), pp. 97-101.

12 Christina Vanja, 'Mining women in early modern European society', in: Thomas Max Safley and Leonard N. Rosenband (eds), The Workplace Before the Factory: Artisans and Proletarians, 1500-1800 (Ithaca and London: Cornell University Press, 1993), pp. 100-117.

13 Sally Zanjani, A Mine of her Own: Women Prospectors in the American West, 1850-1950 (Lincoln, NE and London: University of Nebraska Press, 2006).

14 Such as Ivy Pinchbeck, Women Workers and the Industrial Revolution, 1750-1850 (London: Frank Cass, 1930).

15 Patricia Penn Hilden, Women, Work and Politics, Belgium, 1830-1914 (Oxford: Clarendon Press, 1993), pp. 110-111.

16 Kuntala Lahiri-Dutt, 'Digging women: Towards a new agenda for feminist critiques of mining', Gender, Place and Culture: A Journal of Feminist Geography 19(2) (2012), pp. 193-212.

17 Peter Alexander, 'Women and coal mining in India and South Africa', African Studies 66 (2007), pp. 201-22.

18 Kuntala Lahiri-Dutt, and Martha Macintyre, 'Introduction', in: Kuntala Lahiri-Dutt and Martha Mcintyre (eds), Women Miners in Developing Countries: Pit Women and Others (Aldershot: Ashgate, 2006), pp. 1-18.

19 Masanori Nakamura, Technology Change and Female Labour: Manufacturing Industries of Japan (Tokyo: United Nations University Press, 1994), pp. 15-16.

20 Angela John, By the Sweat of their Brow: Women Workers at Victorian Coal Mines (London: Croom Helm, 1980), p. 30.

21 Nancy Forestell, “"And I feel like I'm dying from mining for gold”: Disability, gender, and the mining community, 1920-1950', Labor Studies in Working-Class History of the Americas 3(3) (2006), pp. 77-93.

22 Melanie Ilič, 'Women workers in the Soviet mining industry: A case study of labour protection', Europe-Asia Studies 48(8) (1996), pp. 1387-1401.

23 Jock McCulloch, 'Women mining asbestos in South Africa', Journal of Southern African Studies 29(2) (2003), pp. 413-432.

24 Jaci Gier and Laurie Mercier (eds), Mining Women: Gender in the Development of a Global Industry, 1670-2005 (New York: Palgrave Macmillan, 2006).

25 Suzanne E. Tallichet, Daughters of the Mountain: Women Coal Miners in Central Appalachia (University Park, PA: The Pennsylvania State University Press; Urbana and Chicago, IL: University of Illinois Press, 2006).

26 Lahiri-Dutt and Macintyre, 'Introduction'. 
27 Ginger Gibson, and Deanna Kemp, 'Corporate engagement with Indigenous women in the minerals industry: Making space for theory', in: Ciaran O'Faircheallaigh and Saleem Ali (eds), Earth Matters: Indigenous Peoples, the Extractive Industries and Corporate Social Responsibility (Sheffield: Greenleaf Publishing, 2008), pp. 104-122.

28 Deanna Kemp, Carol Bond, Daniel Franks, and Claire Cote, 'Mining, water and human rights: Making the connection', Journal of Cleaner Production 15(18) (2010), pp. $1553-1562$.

29 Ciaran O'Faircheallaigh, 'Women's absence, women's power: Indigenous women and negotiations with mining companies in Australia and Canada', Ethnic and Racial Studies 36(11) (2013), pp. 1789-1807.

30 Kate Grosser, and Jeremy Moon, 'Developments in company reporting on workplace gender equality? A corporate social responsibility perspective', Accounting Forum 32(3) (2008), pp. 179-198.

31 David Trigger, Julia Keenan, Kim de Rijke, and Will Rifkin, 'Aboriginal engagement and agreement-making with a rapidly developing resource industry: Coal seam gas development in Australia', The Extractive Industries and Society 1(2) (2014), pp. 176-188.

32 Joni Parmenter, 'Experiences of Indigenous women in the Australian mining industry', in: Kuntala Lahiri-Dutt (ed.), Gendering the Field: Towards Sustainable Livelihoods for Mining Communities (Canberra: ANU E Press, 2011), pp. 67-86.

33 Lahiri-Dutt and Macintyre, 'Introduction'.

34 Martha Macintyre, 'Money changes everything: Papua New Guinean women in the modern economy', in: Mary Patterson and Martha Macintyre (eds), Managing Modernity in the Western Pacific (St Lucia: University of Queensland Press, 2011), pp. 90-120.

35 Martha Macintyre, 'Women and mining projects in Papua New Guinea: Problems of consultation, representation, and women's rights as citizens', in: Ingrid MacDonald and Claire Rowland (eds), Tunnel Vision: Women, Mining and Communities (Fitzroy: Oxfam Community Aid Abroad, 2002), pp. 26-30.

36 Minerals Council of Australia (MCA), MCA Workforce Gender Diversity Review (Canberra: White Paper, 2013).

37 Robyn Mayes, and Barbara Pini, 'The Australian mining industry and the ideal mining woman: Mobilizing a public business case for gender equality', The Journal of Industrial Relations 56(4) (2014), pp. 527-546.

38 Linda Rhodes, Two for the Price of One: The Lives of Mining Wives (Perth: Curtin University Press, 2006).

39 Kathryn Robinson, Stepchildren of Progress: The Political Economy of Development in an Indonesian Mining Town (Albany, NY: State University of New York Press, 1986).

40 Julie-Kathy Gibson-Graham, “"Stuffed if I know!” Reflections on post-modern feminist social research', Gender, Place and Culture 1(2) (1994), pp. 205-224.

41 Linda McDowell, and Doreen Massey, 'Coal mining and place of women: A case of nineteenth century Britain', in: Doreen Massey and John Allen (eds), Geography Matters! A Reader (Cambridge: The Open University, 1984), pp. 128-147.

42 Catherine Pattenden, 'Shifting Sands: Transience, Mobility and the Politics of Community in a Remote Mining Town' (Unpublished PhD thesis) (Discipline of Anthropology and Sociology, School of Social and Cultural Studies, University of Western Australia, 2005).

43 Katy Jenkins, 'Women, mining and development: An emerging research agenda', The Extractive Industries and Society 1(2) (2014), pp. 329-339.

44 Thomas Miller Klubock, Contested Communities: Class, Gender and Politics in Chile's El Teniente Copper Mine, 1904-1951 (Durham, NC: Duke University Press, 1998).

45 June Nash, We Eat the Mines and the Mines Eat Us: Dependency and Exploitation in Bolivian Tin Mines (New York: Columbia University Press, 1979), pp. 12-13. 
46 Mary Murphy, Mining Cultures: Men, Women and Leisure in Butte, 1914-41 (Women in American History), (University of Illinois Press, IL: Illinois, 1997).

47 Jessica Smith Rolston, Mining Coal and Undermining Gender: Rhythms of Work and Family in the American West (New Brunswick: Rutgers University Press, 2014).

48 Kuntala Lahiri-Dutt, 'Gender (plays) in Tanjung Bara mining camp in Eastern Kalimantan, Indonesia', Gender, Place and Culture 20(8) (2013), pp. 979-998.

49 Valerie Gordon Hall, 'Contrasting female identities: Women in coal mining communities in Northumberland, England, 1900-1939', Journal of Women's History 13(2) (2001), pp. 107-131.

50 Zola, Emil, Germinal (G. Charpentier Publishers. Translated into English from the Original French (1885) by Eldritch Press, 1985).

51 Gorky, Maxim, Mother (Translated into English from the Original (1906) Russian by Mahaveer Press, New Delhi, 2012).

52 Caroline Waldron Merithew, "We were not ladies": Gender, class and a women's auxiliary battle for mining unionism', Journal of Women's History 18(2) (2006), pp. 63-94.

53 Karen Beckwith, 'Collective identities of class and gender: Working class women in the Pittston coal strike', Political Psychology 19(1) (1998), pp. 147-167.

54 Georgina Murray, and David Peetz, Women of the Coal Rushes (Sydney: University of New South Wales Press, 2011), p. 288.

55 Jean Stead, Never the Same Again: Women and the Miners' Strike (London: The Women's Press, 1987).

56 Kuntala Lahiri-Dutt (ed.), Gendering the Field: Towards Sustainable Livelihoods in Mining Areas (Canberra: ANU E Press, 2011) Available from: http://epress.anu.edu.au/ gendering_field_citation.html (accessed 9 June 2019).

57 Padmini Sathianadhan Sengupta, Women Workers of India (Mumbai: Asia Publishing House, 1960), p. 67.

58 Leela Fernandes, Producing Workers: The Politics of Gender, Class, and Culture in the Calcutta Jute Mills (Philadelphia, PE: University of Pennsylvania Press, 1997), p. 38 .

59 Lahiri-Dutt, 'The shifting gender of coal'.

60 Jane L. Parpart, 'Class and gender on the copperbelt: Women in Northern Rhodesian copper mining communities, 1926-1964', in: Claire Robertson and Iris Berger (eds), Women and Class in Africa (New York and London: Africana Publishing Company, 1986), pp. 141-160.

61 William Hipwell, Katy Mamen, Viviane Weitzner, and Gail Whiteman, Aboriginal People and Mining in Canada: Consultation, Participation and Prospects for Change (Working Discussion Paper, North-South Institute, 2002).

62 Nesar Ahmad and Kuntala Lahiri-Dutt, 'Engendering mining communities: Examining the missing gender concerns in coal mining displacement and rehabilitation in India', Gender, Technology and Development 10(3) (2007), pp. 313-339.

63 Sharmistha Bose, 'Positioning women within the environmental justice framework: A case from the mining sector', Gender, Technology and Development 8(3) (2004), pp. 407-412.

64 K. Bhanumathi, 'Mines, minerals and PEOPLE, India', in: Ingrid MacDonald and Claire Rowland (eds), Tunnel Vision: Women, Mining and Communities (Victoria: Oxfam, 2002), pp. 20-24.

65 Robinson, Stepchildren of Progress, p. 12.

66 Indira Rothermund, 'Women in a coal mining area', Indian Journal of Social Science 7(3-4) (1994), pp. 251-264.

67 Kuntala Lahiri-Dutt, and Petra Mahy, Impacts of Mining on Women and Youth in Two Locations in East Kalimantan, Indonesia (2007). Report available from http://empow eringcommunities.anu.edu.au (accessed on 11 September, 2008). 


\section{Kuntala Lahiri-Dutt}

$68 \mathrm{Ibid}$.

69 Atu Emberson-Bain, 'Atu. De-romancing the stones: Gender, environment and mining in the Pacific', in: Atu Emberson Bain (ed.), Sustainable Development of Malignant Growth? Perspectives of Pacific Island Women (Suva: Marama Publications, 1994), pp. 91-110.

70 Macintyre, Martha, 'Women and mining projects in Papua New Guinea', pp. 26-30.

71 Lahiri-Dutt (ed.), Gendering the Field: Towards Sustainable Livelihoods in Mining Areas.

72 O'Faircheallaigh, 'Women's absence, women's power'.

73 Lahiri-Dutt, 'The shifting gender of coal'.

74 Christina Hill, and Kelly Newell. Women, Communities and Mining: The Gender Impacts of mining and the role of gender impact assessment (Melbourne: Oxfam Australia, 2009). 